\title{
Tinjauan
Pustaka \\ Tinjauan
Pustaka
}

\begin{abstract}
ABSTRAK
Pendahuluan: Penyakit pernapasan yang dinamakan novel coronavirus disease 2019 (COVID-19) dan disebabkan oleh severe acute respiratory syndrome-Coronavirus-2 (SARS-CoV-2) pertama kali muncul di kota Wuhan, Republik Rakyat Tiongkok. Lebih lanjut, penyebaran eksponensialnya memaksa para pemegang kekuasaan untuk menerapkan kebijakan-kebijakan lockdown serta pembatasan fisik untuk berusaha menghentikan penyebaran virus. Akan tetapi, isolasi masal hanya memunculkan problema-problema lainnya, terutama peningkatan prevalensi depresi dan generalized anxiety disorder (GAD). Kedua gangguan mental tersebut telah diamati mengalami peningkatan selama pandemi akibat beberapa faktor risiko. Tinjauan pustaka diharapkan mampu mengungkap kejelasan faktor tersebut serta menentukan penyebab-penyebab utama dari peningkatan prevalensi tersebut.

Metode: Tinjauan dilakukan sesuai panduan PRISMA (Preferred Reporting Items for Systematic Reviews and Meta-Analysis) dari beberapa database daring, termasuk: PubMed, Cochrane, Sciencedirect, Wiley Online Library, dan EBSCOhost.

Pembahasan: Hasil penelusuran literatur kemudian dianalisis dari 401 artikel, 5 artikel dipilih berdasarkan kriteria inklusi. Kelimanya menyepakati beberapa faktor, yaitu: status pelajar, jenis kelamin, kondisi kesehatan yang sudah ada sebelumnya, serta manajemen emosi sebagai faktor risiko utama depresi dan GAD.

Simpulan: Faktor-faktor risiko tersebut selayaknya dipertimbangkan oleh para pembuat kebijakan dalam menyusun langkah-langkah perlindungan terhadap COVID-19 beserta pandemi lainnya di masa depan untuk meminimalisir dampaknya terhadap kesehatan mental pelajar dan masyarakat secara keseluruhan.
\end{abstract}

Kata Kunci: covid-19, depresi, kecemasan, pandemi, pelajar

\section{ABSTRACT}

Background: The respiratory disease named novel coronavirus disease 2019 (COVID-19) was caused by the Severe acute respiratory syndrome-Coronavirus-2 (SARS-CoV-2) originated initially in Wuhan, China. Furthermore, the exponential spread of the virus forced many officials to employ strict lockdown and physical distancing measures to halt the transmission. Despite this, mass isolation only surfaces a plethora of problems, especially the increased prevalence in depression and generalized anxiety disorder (GAD). Both mental illnesses have been shown to increase during the pandemic due to a myriad of risk factors. Thus, in this study we aim to shed light on those risk factors, via a systematic review to determine which are the pivotal reasons for the increasing prevalence

Methods: The review is done in accordance to the PRISMA (Preferred Reporting Items for Systematic Reviews and Meta-Analysis) guideline from a few online databases including: PubMed, Cochrane, Sciencedirect, Wiley Online Library, dan EBSCOhost 
Discussion: After analyzing 401 articles, 5 articles were chosen based on the inclusion criteria. The articles unanimously agreed on a few factors, namely: student status, gender, preexisting health conditions, and also emotional management as main risk factors of depression and $G A D$

Conclusion: In conclusion, those risk factors should be put into consideration by policy makers in crafting protective measures against COVID-19 and other pandemics in the future in order to minimize its impact on the mental health of students and the overall community.

Keywords: anxiety, covid-19, depression, pandemic, student

\section{PENDAHULUAN}

Pandemi novel coronavirus disease 2019 (COVID-19) membawa penyakit pernapasan yang dikenal sebagai severe acute respiratory syndrome-Coronavirus-2 (SARS-CoV2). Penyakit corona virus disease 2019 (COVID-19) bermula pada kota Wuhan di China pada Desember 2019 dan beberapa bulan kemudian ditetapkan sebagai pandemi global pada tanggal 11 Maret 2020 oleh World Health Organisation (WHO). Kasus pertama COVID-19 di Indonesia resmi ditemukan pada tanggal 2 Maret 2020. Penemuan tersebut kemudian dilanjutkan dengan pembuatan peraturan dan respons untuk mengantisipasi penyebaran COVID-19 di Indonesia. Berbeda dengan beberapa negara yang melakukan lockdown, pemerintahan Indonesia membuat keputusan untuk mengimplementasikan Pembatasan Sosial Berskala Besar (PSBB). Walaupun masyarakat berkepentingan masih mempunyai hak untuk bepergian, mayoritas penduduk Indonesia melakukan kerja dari rumah dengan harapan rantai penyebaran COVID-19 terhentikan. ${ }^{[1]}$

Secara klinis, gejala-gejala umum yang ditunjukkan oleh pasien COVID-19 adalah demam, batuk kering, dan juga napas singkat. Manifestasi klinis yang lebih buruk dapat berupa pneumonia dan juga acute respiratory distress syndrome (ARDS) yang merupakan penyebab kematian dari COVID-19 yang utama.[2,3] Selain itu, SARS-CoV-2 juga dapat menyebabkan gangguan fisiologis di luar sistem pernapasan.[3] Terdapat beberapa indikasi bahwa SARS-CoV-2 mempunyai properti neurotropik yang menyebabkan beberapa gejala neurologis pada pasien COVID-19..[3] Selain itu, strategi utama pemutusan rantai penyebaran COVID-19 adalah berbagai bentuk physical distancing atau pembatasan fisik. ${ }^{[1]}$ Walau mengatasi transmisi COVID-19, solusi ini menimbulkan beberapa komplikasi berantai, di antaranya terhadap perekonomian dan menurut Huang \& Zhao (2020), kesehatan mental masyarakat, terutama depresi serta generalized anxiety disorder (GAD). ${ }^{[2,4]}$

Depresi merupakan sebuah gangguan medis kronik yang dapat mempengaruhi pikiran, suasana hati, hingga kesehatan jasmani. Mood rendah (distimia), lemas, sedih, insomnia, dan ketidakmampuan untuk menikmati hidup termasuk ke dalam karakteristikkarakteristik yang menandai depresi. Sebagai penyebab peringkat ketiga dari beban penyakit global WHO pada tahun 2008 serta diperkirakan akan menjadi nomor satu di 2030), depresi sangat membatasi fungsi psikososial dan menurunkan kualitas hidup seseorang. $[5,6]$

Riset Kesehatan Dasar Kementerian Kesehatan pada tahun 2018 menunjukkan bahwa gangguan depresi telah mulai terjadi sejak masa remaja (15-24 tahun) dengan prevalensi $6,2 \%$. Seiring bertambahnya usia, prevalensi depresi juga semakin meningkat. Pada orang-orang dalam rentang usia 55-64 tahun, sebanyak $6,5 \%$ diantaranya menderita depresi. Angka tersebut melonjak menjadi $8 \%$ di kalangan 65-74 tahun. Kelompok usia 75 tahun ke atas, depresi memiliki prevalensi tertinggi, yakni sebesar $8,9 \%$. Berbagai persentase ini berkontribusi kepada angka rerata prevalensi depresi nasional (pada penduduk berusia $\geq 15$ tahun), yaitu $6,1 \%$. ${ }^{[7]}$

Generalized Anxiety Disorder (GAD) atau disebut juga gangguan ansietas secara umum merupakan suatu kondisi psikososial yang menyebabkan ketakutan, kekhawatiran dan juga perasaan kewalahan yang berterusan. 
Selain itu, GAD juga dikarakteristikkan dengan kekhawatiran yang berlebihan dan tidak normal terhadap kegiatan sehari-hari dari aspek keluarga, kesehatan, keuangan, dan juga masa depan. ${ }^{[8]}$

Survei epidemiologis yang telah dilakukan menunjukkan bahwa GAD seumur hidup memiliki prevalensi $4.3 \%-$ $5.9 \%$ di populasi secara general dan lebih banyak dialami oleh wanita. Namun, ada juga prevalensi GAD yang dapat disembuhkan dalam 12 bulan yang memiliki prevalensi rendah pada $0.2 \%$ $4.3 \%$ dan juga GAD yang disembuhkan dalam 1 bulan yang memiliki prevalensi lebih tinggi pada 7.9-9\%. Prevalensi yang cukup tinggi pada GAD 1 bulan disebabkan oleh tatalaksana GAD yang dini. Namun, persentase dari GAD 1 bulan tidak jauh berbeda dengan GAD seumur hidup. Hal tersebut dikarenakan apabila seorang telah didiagnosis dengan GAD dan tidak diberi tatalaksana yang sesuai dalam waktu singkat, maka GAD akan menjadi kronis dan pasien tersebut akan tetap mengalami gejalagejala GAD hingga 12 tahun setelah diagnosis dilakukan..$^{[9]}$

Survei yang telah dilakukan pada 7.236 responden di China juga mengindikasikan adanya peningkatan prevalensi gejala gangguan kesehatan mental sejak pandemi COVID-19. Klaim ini dibuktikan oleh $35.1 \%$ responden yang menunjukkan gejala depresi dan $20.1 \%$ menunjukkan gejala GAD. Gejalagejala gangguan mental ini lebih banyak ditemukan pada responden lebih muda yang mayoritas merupakan pelajar. Tingkat prevalensi ini disebabkan oleh kecenderungan mereka mengkhawatirkan dampak-dampak dari COVID-19. Akan tetapi, masih terdapat faktor-faktor lain yang dapat memperparah peningkatan gejala-gejala depresi dan GAD pada pelajar selama pandemi COVID-19 ini berlangsung. ${ }^{[4]}$

Urgensi mengenai dampak psikososial dan potensi gejala-gejala tersebut dalam mengganggu kualitas hidup pelajar perlu ditinjau. Kajian literatur diharapkan mampu mencakup faktor-faktor risiko penyebab berbagai gejala GAD dan depresi selama pandemi COVID-19 dengan melakukan analisis sistematis terhadap literatur yang relevan dalam bentuk scoping review. Tinjauan pustaka diharapkan mampu menjadi rujukan bagi penelitian selanjutnya maupun dasar bagi pengambilan kebijakan selama pandemi terhadap kalangan pelajar.

\section{METODE}

Scoping review
berdasarkan panduan PRISMAn
(Preferred Reporting Items for
Systematic Reviews and Meta-Analysis) statement dari database daring yaitu PubMed, Cochrane, Sciencedirect, Wiley Online Library, dan EBSCOhost dengan kata kunci: [(Depression) AND ((COVID19) OR (Pandemic)) AND (Student)], AND [(Generalized Anxiety Disorder) AND ((COVID-19) OR (Pandemic)) AND (Student)]. Alur pencarian literatur disusun seperti pada diagram alir (Gambar 1).

Kriteria inklusi untuk menyaring pustaka, yaitu: studi observasional baik crosssectional dan cohort serta penelitian identifikasi efek pandemi COVID-19 pada kesehatan mental di kalangan usia dewasa muda. Selain itu, kriteria eksklusi berupa akses artikel berbayar, jenis studi tidak diketahui, studi dengan data yang tidak dapat diekstrak, tidak ditulis dalam bahasa Inggris, serta artikel review. Selanjutnya, data dan ringkasan dari literatur diekstrak dan dibahas pada Tabel 1. Untuk ringkasan yang mencangkupi lokasi, desain studi, waktu studi, ukuran sampel, dan ratarata/mayoritas usia sampel, dapat dilihat di Lampiran 1. Penilaian kualitas literatur dilakukan berdasarkan pedoman $\mathrm{NIH}$ Quality Assessment Tool for CrossSectional Studies yang digunakan untuk menilai studi observasional serta dirangkum pada Lampiran 2. 


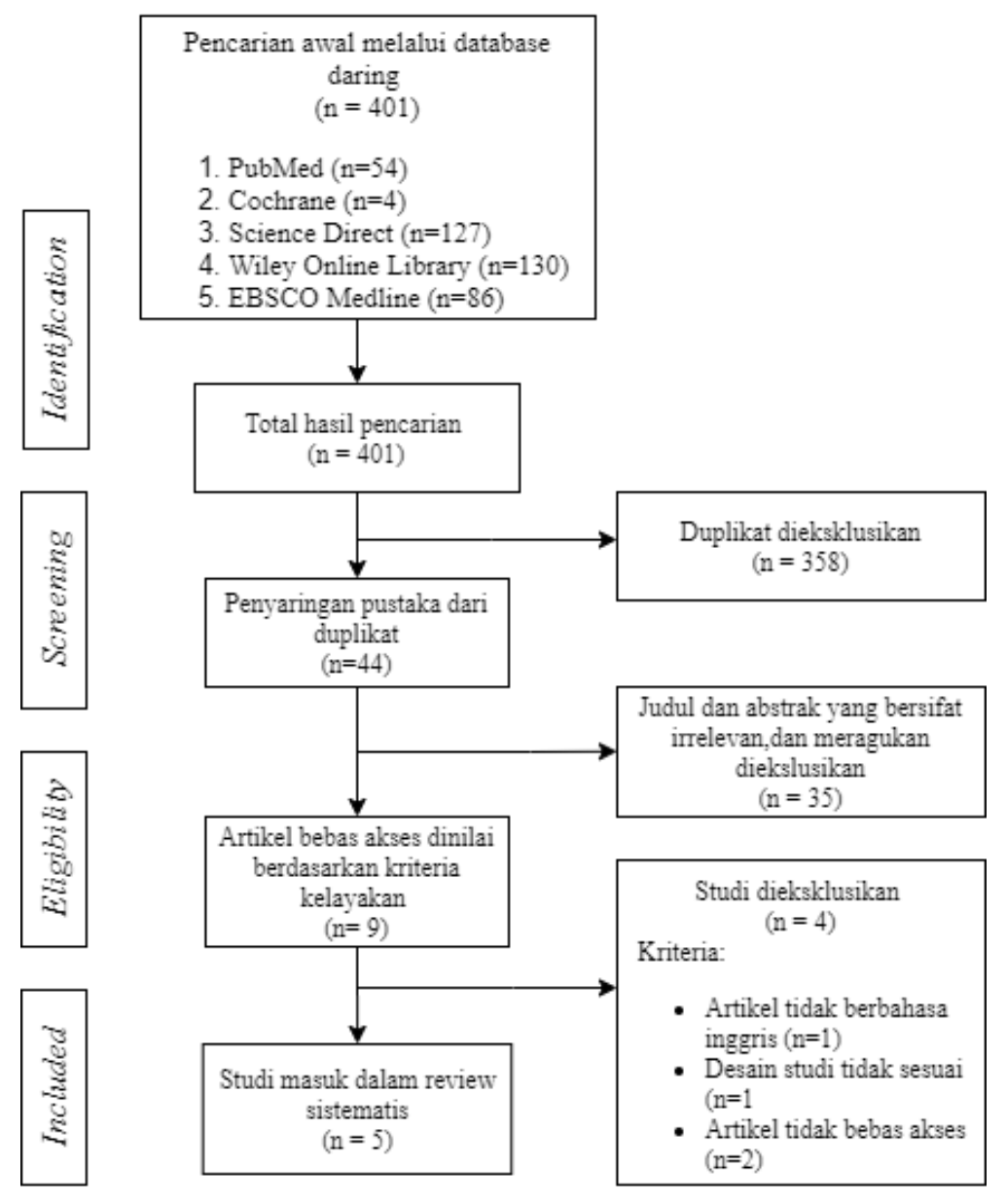

Gambar 1. Strategi Pencarian Literatur

\section{PEMBAHASAN}

\subsection{Gangguan Kesehatan Mental} American

Psychiatric

Association (APA) mendefinisikan gangguan mental sebagai kondisi kesehatan yang ditandai dengan adanya perubahan pada emosi, pola pikir, dan juga perilaku seseorang (atau mungkin juga kombinasi dari ketiga aspek tersebut). [10] Indikasi dari gangguan mental tentunya berbeda-beda tergantung dengan jenis gangguan tersebut, namun secara general, gangguan mental dapat diasosiasikan dengan adanya kesulitan atau masalah terintegrasi dalam kegiatan sosial, keluarga, ataupun pekerjaan. [10,11] Diantaranya, depresi dan Generalised Anxiety Disorder (GAD) merupakan gangguan mental yang mempunyai prevalensi tertinggi secara global. [11] Selain itu, karena mayoritas literatur yang membahas mengenai topik gangguan mental selama pandemi
COVID-19 lebih berfokus kepada ansietas dan depresi, analisis ini akan lebih mendalami kedua jenis gangguan tersebut.

\subsection{Depresi}

Meskipun faktor sosial dan budaya, seperti status sosial ekonomi dapat berperan dalam menyebabkan depresi, genomik dan faktor-faktor biologis lain pada akhirnya mendorong terjadinya kondisi ini. Akan tetapi, penelitian depresi dengan model hewan telah mengidentifikasi beberapa mekanisme yang relevan terhadap penyakit ini. Pertama, pembedahan olfactory bulbectomy bilateral (OBX) pada tikus dan mencit menunjukkan hasil berupa disfungsi dan degenerasi neuronal sirkuit-sirkuit kortikalhipokampus-amigdala. Defisit kognitif, pengurangan libido, pengurangan interaksi sosial, defisit ingatan spasial dan emosional juga diasosiasikan 
dengan kerusakan pada berbagai sirkuit tersebut. Pada manusia, hubungan jelas antara OBX dan depresi masih kontroversial, tetapi terdapat korelasi negatif yang signifikan antara volume olfactory bulb dan tingkat keparahan depresi. Kedua, pemisahan maternal dan stres akibat peristiwa traumatis di awal kehidupan berkontribusi pada terbentuknya variasi kemampuan individu untuk bereaksi dan mengatasi peristiwa stres di masa depan. Model ketiga adalah learned helplessness (LH), yaitu keengganan untuk menghindari stimulus negatif yang disebabkan oleh paparan sebelumnya terhadap stres tak terkendali ini ditafsirkan sebagai mekanisme koping mirip depresi yang tak ada pada situasi yang dapat dihindari. Etiologi potensial lainnya antara lain stres pengekang berulang (repeated restraint stress), stres kronik yang tidak dapat diprediksi/ringan, isolasi sosial, stres perundungan, menjadi saksi peristiwa traumatis, serta model rodensia dengan polimorfisme gen BDNF (brainderived neurotrophic factor) Val66Met dan pemberian kortison kronik. [12]

$$
\text { Dalam mengidentifikasi }
$$

perkembangan depresi pada manusia, tidak ada suatu mekanisme tunggal yang dapat melatarbelakangi semua aspek dari penyakit ini. Bahkan, pasien dengan gejala depresi episodik dapat memiliki patofisiologi yang khas pula di episode yang berbeda. Tipe stresor (psikososial dan biologis) juga akan berpengaruh terhadap patofisiologi serta patogenesis depresi yang dialami seseorang. Terdapat sejumlah mekanisme patofisiologi yang masing-masing berkontribusi secara variatif terhadap kasus-kasus penelitian klinik dari depresi. Pertama, hipotesis monoamin menyoroti peran kelompok neurotransmitter ini (serotonin, noradrenalin, dan dopamin) dan defisitnya dalam patogenesis depresi. Kedua, pada kasus-kasus depresi parah dengan gejala melankolik, peningkatan jumlah kortisol plasma akibat pelepasan kortisol stress-related dan disfungsi penghambatan umpan balik dimediasi reseptor glukokortikoid menjadi salah satu temuan biologis yang paling konsisten serta diasosiasikan dengan perubahan-perubahan pada aksis hipotalamus-pituitari-adrenal. Ketiga, inflamasi dan sitokin perifer dapat mempengaruhi neuron serta sel penyokongnya secara langsung, sehingga dapat menjelaskan mengapa individu dengan penyakit autoimun dan infeksi parah lebih mungkin mengalami depresi. Peran inflamasi dalam penyebab dan eksaserbasi depresi selanjutnya didukung oleh temuan bahwa peningkatan jumlah interleukin 6 di masa kanak-kanak meningkatkan risiko seseorang menderita depresi di kemudian hari, serta ditandai oleh bukti aktivasi mikroglial dan peradangan saraf di otak pasien depresi yang diperiksa postmortem. Keempat, baik model hewan maupun studi klinis telah menghubungkan trauma usia dini kepada depresi melalui perubahan dalam aksis HPA, terutama hipofungsi reseptor glukokortikoid. Secara khusus, paparan awal terhadap kesulitan masa kanak-kanak menghasilkan metilasi DNA dari situs kunci dalam gen reseptor glukokortikoid, mengurangi ekspresinya. Mekanisme-mekanisme patofisiologis lainnya yang berpotensi untuk diteliti lebih lanjut mencakup neurogenesis di otak, faktor genetik, dan epigenetik. [5]

Seperti yang telah disinggung sebelumnya, stresor psikososial akan mempengaruhi patofisiologis dari depresi. ${ }^{[5,12]}$ Tergantung dengan kuatnya stresor tersebut, maka manifestasi depresi pada subjek dapat bervariasi. Dewasa ini, Keadaan sosial yang dibawakan oleh pandemi COVID-19 telah menempatkan dirinya sebagai salah satu stresor psikososial yang menyebabkan peningkatan prevalensi depresi di masyarakat. ${ }^{[4]}$ Survey yang dilakukan oleh Huang et al. menuliskan $20 \%$ dari total 7.236 responden yang menunjukkan gejala-gejala depresi. Angka yang relatif tinggi tersebut disebabkan oleh: adanya ketidakpastian kapan pandemi akan selesai dan perasaan hipokondriasis (khawatir akan terinfeksi) dan progresivitas pandemi yang mungkin sulit untuk ditangani. [4]

\subsection{Ansietas}

Sampai saat ini, penyebab pasti dari GAD masih belum disepakati karena spektrum manifestasi klinisnya yang cukup luas sehingga adanya gejalagejala psikologis yang bersifat nonspesifik selain gejala-gejala dari GAD. 
Namun, beberapa agen lain juga teridentifikasi dapat menjadi etiologi dari GAD yang terdiri dari: stres, kondisi fisik orang tersebut, dan paparan eksergonik dalam bentuk kekerasan ataupun narkotika. [8] Selain itu, terdapat beberapa faktor yang dapat menyebabkan GAD, di antaranya pembawaan keluarga yang buruk, kejadian hidup yang traumatis, influensi genomik, dan juga disfungsi secara neurobiologis. [9] Disfungsi tersebut disebabkan oleh kejanggalan pada sistem caraka kimia atau neurotransmitter, terutama yang melibatkan serotonin, epinefrin/norepinefrin, dan juga Gamma Aminobutyric Acid (GABA). Apabila ditinjau secara struktural, pasien dengan GAD memiliki beberapa abnormalitas yang terletak pada korteks prefrontal dan juga amygdala. [9]

Spektrum gangguan ansietas secara umum dihubungkan kepada berbagai komponen kimiawi sistem saraf, antara lain serotonin, GABA, dopamin, norepinefrin, dan masih banyak lagi. Kelainan fungsi dari zat-zat tersebut dan reseptornya di otak telah diidentifikasi sebagai penyebab gangguan ansietas. Pada kasus Generalized Anxiety Disorders, aktivitas berlebih sistem noradrenergik, disregulasi reseptor serotonin (5-HT1A, 5-HT2C), dan penurunan jumlah situs benzodiazepin pada kompleks reseptor GABAA-benzodiazepin menjadi kondisi patofisiologis yang biasanya diasosiasikan

dengan kemunculan gangguan tersebut. Bersama-sama, faktor-faktor ini memicu kondisi fisiologis baseline yang mengalami disregulasi pada individu dengan GAD. Oleh karenanya, timbul gejala-gejala eksitasi berlebih berupa HRV rendah, denyut jantung tinggi, serta tingkat konduktansi kulit yang lebih tinggi dibandingkan kontrol dan individu dengan gangguan ansietas lainnya. [13]

Salah satu penyebab etiologis dari GAD adalah kejadian yang cukup traumatis. Berbagai perubahan dan juga kondisi sukar yang diakibatkan COVID19 dapat bersifat traumatis bagi beberapa orang. Hal tersebut ditunjukkan dalam survei oleh Huang et al. yang menunjukkan bahwa $33.3 \%$ dari responden mereka menunjukkan indikasi gejala-gejala dari GAD. Lebih dari itu, persentase tersebut tidak menunjukkan adanya kecenderungan gender seperti penelitian-penelitian prevalensi GAD yang telah dilakukan sebelumnya. Intensitas gejala GAD pada subjek selama pandemi diperkirakan sesuai dengan jumlah waktu mereka mengkonsumsi informasi mengenai COVID-19. ${ }^{[4]}$ Golongan muda yang baru pertama kali merasakan kondisi pandemi merupakan golongan tertinggi dengan gejala-gejala GAD. Peristiwa ini mungkin disebabkan oleh kurangnya pengalaman dan juga kecenderungan mereka untuk memikirkan COVID-19 secara berlebih yang meningkatkan kekhawatiran. ${ }^{[4]}$

\subsection{Hasil}

Total mahasiswa yang menjadi responden dalam kumpulan studi yang kami tinjau adalah berjumlah sebanyak 365.963 orang. Adapun mayoritas kelompok usia responden berada di angka 17-31 tahun. Empat dari lima studi didapatkan dari populasi negara Tiongkok, kecuali satu studi crosssectional yang diadakan di Bangladesh. Hasil penelitian diperoleh dari metode yang bervariasi, yakni simple cluster, cluster, snowball, dan convenience sampling. Semua metode pengambilan sampel diaplikasikan menggunakan survei daring.

\subsection{Diskusi}

Kajian literatur yang telah kami lakukan menunjukkan bahwa terdapat beberapa faktor risiko umum dari depresi dan ansietas selama pandemi yang diidentifikasi oleh kelima studi. Jenis kelamin perempuan, durasi karantina yang lama, kekhawatiran terinfeksi, status pelajar (semakin tinggi tingkat pendidikan, semakin buruk), status kesehatan, manajemen emosional yang rendah, dan jarak tempat tinggal dari zona infeksius (contohnya Wuhan) menjadi faktor-faktor yang berpotensi untuk mengeksaserbasi gejala-gejala depresi serta ansietas. ${ }^{[14-18]}$ Xiao $\mathrm{H}$ et al. melaporkan bahwa secara umum, pemikiran-pemikiran serta tindakan negatif memprediksi dampak yang lebih besar dari ansietas $(\beta=0,87)$ dan depresi $(\beta=0.86)$. Selain itu, pada penelitian yang sama, ansietas dan depresi lazim dialami oleh responden 
dengan durasi screen time per hari yang lebih lama (>4 jam) dan gaya hidup yang kurang sehat (irama tidur dan makan tidak teratur).[4]

Hal yang tidak jauh berbeda dikemukakan pula dalam penelitian oleh Chen $\mathrm{R}$, di mana waktu tidur yang tidak teratur diidentifikasi sebagai salah satu faktor berbahaya terhadap gejala depresi $(\mathrm{OR}=1.58,95 \% \mathrm{Cl}:$ 1.43-1.73, $\mathrm{p}<.001){ }^{[17]}$ Penemuan konsisten lainnya oleh Khan $\mathrm{AH}$ et al. ialah bahwa lamanya waktu yang dihabiskan seseorang untuk menjelajahi informasi mengenai COVID19 dalam sehari (>5 jam) dan paparan melalui media sosial serta berita menjadi faktor risiko bagi gejala-gejala depresi jika diukur dengan skala PHQ-9 dan DASS 21.[18] Salah satu penelitian juga menggarisbawahi ketidakpastian finansial dan kelangkaan persediaan makanan di rumah sebagai faktor risiko baik bagi depresi maupun ansietas. Di sisi lain, dari kelima studi, faktor-faktor yang diasosiasikan sebagai faktor proteksi terhadap gejala depresi serta ansietas terdiri dari informasi medis akurat, perilaku hidup bersih dan sehat (taat memakai masker, mencuci tangan, dan sanitasi), olahraga cukup, makan teratur, dan rekreasi. [14-18]
Studi ini memiliki beberapa kelebihan dan juga limitasi yang patut dipertimbangkan. Secara keseluruhan, kelebihan dari literatur-literatur yang ditinjau terletak pada keseragaman metode penelitian serta jumlah total responden yang besar. Sementara itu, limitasi yang ada dapat dijabarkan menjadi beberapa aspek. Pertama, tinjauan literatur yang telah dilakukan masih terbatas pada kurangnya jumlah literatur relevan yang tersedia. Kedua, desain kelima studi yang bersifat crosssectional membatasi kemampuan untuk membuat inferensi-inferensi kausal. Ketiga, metode pengumpulan sampel yang digunakan cenderung berupa jenis non-probability sampling. Akibatnya, masih terdapat kemungkinan risiko bias dalam pemilihan sampel. Secara umum berdasarkan panduan dalam menilai kualitas studi cohort yang dirangkup pada Lampiran 2, ditemukan bahwa terdapat 3 studi yang tergolong baik, sedangkan lainnya dapat dinilai berkualitas cukup. Setiap studi menggunakan survei daring di mana responden mengisi secara mandiri, sehingga memungkinkan adanya beberapa ketidaktepatan dalam mengisi dan berdampak pada hasil yang diakumulasi. 
Tabel 1. Ringkasan Studi

\begin{tabular}{|c|c|c|c|}
\hline NO & $\begin{array}{c}\text { Penulis } \\
\text { dan } \\
\text { Tahun }\end{array}$ & $\begin{array}{l}\text { Metode Pengukuran } \\
\text { dan Klasifikasi }\end{array}$ & Hasil Penelitian \\
\hline 1 & $\begin{array}{l}\text { Wang } \\
\text { C, } \\
2020^{[14]}\end{array}$ & 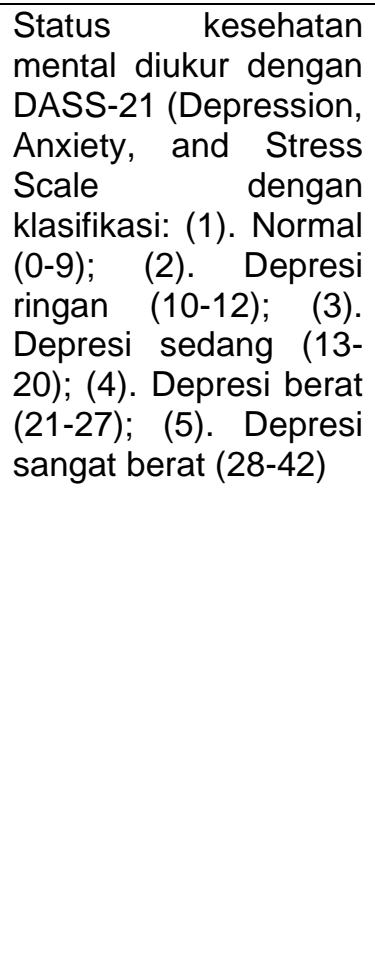 & $\begin{array}{l}\text { Sejumlah } 53,8 \% \text { responden menilai dampak } \\
\text { psikologis dari wabah tergolong sedang atau } \\
\text { parah; } 16,5 \% \text { melaporkan gejala depresi sedang } \\
\text { hingga berat; } 28,8 \% \text { melaporkan gejala } \\
\text { kecemasan sedang hingga berat; dan } 8,1 \% \\
\text { melaporkan tingkat stres sedang hingga berat. } \\
\text { Sebagian besar responden menghabiskan } 20-24 \\
\text { jam per hari di rumah ( } 84,7 \%) \text {; khawatir anggota } \\
\text { keluarga mereka tertular COVID-19 ( } 75,2 \%) \text {; dan } \\
\text { merasa puas dengan jumlah informasi kesehatan } \\
\text { yang tersedia ( } 75,1 \%) \text {. Jenis kelamin perempuan, } \\
\text { status pelajar, gejala fisik tertentu (misalnya, } \\
\text { mialgia, pusing, coryza), dan status kesehatan } \\
\text { yang dinilai buruk secara signifikan terkait dengan } \\
\text { dampak psikologis yang lebih besar dari wabah } \\
\text { dan tingkat stres, kecemasan, dan depresi yang } \\
\text { lebih tinggi ( } p<0,05) \text {. Adaya informasi kesehatan } \\
\text { yang terkini dan akurat (misalnya, pengobatan, } \\
\text { situasi wabah lokal) dan tindakan pencegahan } \\
\text { tertentu (misalnya, kebersihan tangan dan } \\
\text { memakai masker) menunjukkan dampak } \\
\text { psikologis yang lebih rendah dari wabah dan } \\
\text { tingkat stres yang lebih rendah, kecemasan, dan } \\
\text { depresi ( } p<0,05) \text {. }\end{array}$ \\
\hline 2 & $\begin{array}{l}\text { Feng Y, } \\
2020^{[15]}\end{array}$ & 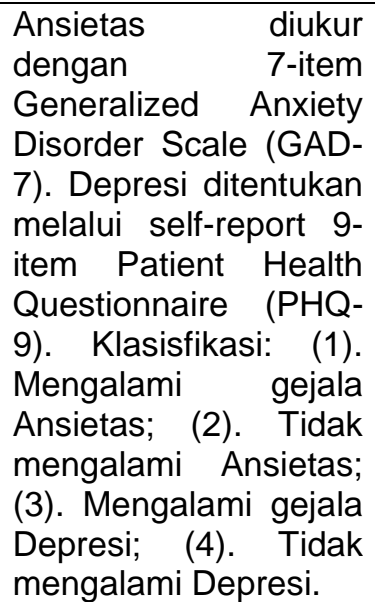 & $\begin{array}{l}\text { Semakin tinggi risiko yang dirasakan responden, } \\
\text { semakin banyak pengaruh negatif yang mereka } \\
\text { tunjukkan }(\beta=0,16, p<0,001) \text {, dan dengan } \\
\text { demikian, responden merasa lebih cemas dan } \\
\text { tertekan }(\beta=0,134, p<0,001) \text {; Namun, hubungan } \\
\text { antara persepsi risiko dan pengaruh negatif ini } \\
\text { dimoderasi oleh altruisme. }\end{array}$ \\
\hline 3 & $\begin{array}{l}\text { Xiao H, } \\
2020^{[16]}\end{array}$ & $\begin{array}{lr}\text { Ansietas } & \text { diukur } \\
\text { dengan } & \text { 7-item } \\
\text { Generalized Anxiety } \\
\text { Disorder Scale (GAD- } \\
\text { 7). Depresi ditentukan } \\
\text { melalui self-report 9- } \\
\text { item Patient Health } \\
\text { Questionnaire (PHQ- } \\
\text { 9). Klasifikasi: (1). } \\
\text { Normal; (2). Ringan; } \\
\text { (3). Sedang; (4). Berat }\end{array}$ & $\begin{array}{l}\text { Dari sejumlah } 933 \text { siswa, } 898(96,2 \%) \text { melaporkan } \\
\text { sering memakai masker saat keluar, } 723(77,5 \%) \\
\text { melaporkan mencuci tangan setiap hari dengan } \\
\text { sabun, } 676(72,5 \%) \text { mencuci tangan segera } \\
\text { setelah tiba di rumah, dan } 914(98,0 \%) \text { melaporkan } \\
\text { tinggal di rumah sebanyak mungkin. Prevalensi } \\
\text { gangguan kecemasan } 17,1 \% \text { dan depresi } 25,3 \% \text {. } \\
\text { Regresi logistik multivariabel menunjukkan } \\
\text { kecemasan dikaitkan dengan status mahasiswa } \\
\text { pascasarjana (rasio odds (aOR) }=2.0 \text {; interval } \\
\text { kepercayaan 95\% (Cl): 1.2-3.5), pikiran atau } \\
\text { tindakan negatif (aOR }=1.6 ; 95 \% \mathrm{Cl}: 1.4-1.7) \text {, dan } \\
\text { merasa tertekan (aOR = } 6.8 ; 95 \% \mathrm{Cl}: 4.0-11.7) \text {. } \\
\text { Mahasiswa Beijing secara signifikan lebih kecil } \\
\text { kemungkinannya untuk mengalami kecemasan }\end{array}$ \\
\hline
\end{tabular}


e-ISSN: 2721-1924

ISSN: 2302-6391

dibandingkan dengan mereka yang berada di episentrum wabah yaitu di Wuhan (aOR $=0,9 ; 95 \%$ Cl: 0,8-1,0), tetapi depresi tidak berbeda. Depresi dikaitkan dengan mahasiswi $(\mathrm{aOR}=2.0 ; 95 \% \mathrm{Cl}$ : 1.2-3.3), pikiran atau tindakan negatif $(\mathrm{aOR}=1.7$; $95 \% \mathrm{Cl}: 1.5-1.9$ ), dan gangguan kecemasan (aOR $=5.8 ; 95 \%$ Cl: 3.4-9.9)

\begin{tabular}{lll}
\hline $4 \quad$ Chen & Depresi ditentukan \\
$\mathrm{R}$, & melalui self-report 9- \\
$2020^{[17]}$ & item Patient Health \\
& Questionnaire (PHQ- \\
& 9). Klasifikasi: (1). \\
& Mengalami gejala \\
& Depresi; (2). Tidak \\
& mengalami Depresi.
\end{tabular}

Sejumlah $7,7 \%$ mahasiswa menunjukkan gejala depresi selama pandemi COVID-19. Mahasiswa dengan gejala depresi berkaitan dengan kemampuan manajemen emosinya yang rendah. Kegiatan menjelajahi informasi COVID-19 selama 3 jam per hari terbukti berhubungan dengan gejala depresi. Ritme hidup yang tidak menyenangkan ditemukan berpengaruh dengan munculnya gejala depresi.

\begin{tabular}{lll}
\hline 5 & Khan & Status kesehatan \\
AH, & mental diukur dengan \\
$2020^{[18]}$ & DASS-21 (Depression, \\
& Anxiety, and Stress \\
& Scale) $\quad$ dengan \\
& klasifikasi: (1). Normal \\
& (0-9); (2). Depresi \\
& ringan (10-12); (3). \\
& Depresi sedang (13- \\
& 20); (4). Depresi berat \\
& (21-27); (5). Depresi \\
& Sangat berat (28-42). \\
& Kondisi distres diukur \\
& dengan Impact of \\
& Event Scale (IES)
\end{tabular}

Sejumlah $28,5 \%$ dari responden mengalami stres, $33,3 \%$ kecemasan, $46,92 \%$ depresi dari ringan hingga sangat parah, berdasarkan DASS 21 dan $69,31 \%$ memiliki distress khusus dari tahap ringan hingga berat dalam hal tingkat keparahan melalui survei IES. Responden yang menyadari adanya gejala fisik sebagai COVID-19 secara signifikan dikaitkan dengan subskala stres DASS $(B=3,71$, Cl 95\%: 1,01 hingga 6,40), subskala kecemasan DASS ( $\mathrm{B}=3,95, \mathrm{Cl}$ 95\%: 1,95 hingga 5,96), subskala depresi DASS (B=3,82, $\mathrm{Cl} 95 \%$ : 0,97 hingga 6,67 ) dan skala IES (B = 7,52, CI 95\%: 3,58 hingga 11,45$)$. Selain itu, ketakutan akan infeksi, ketidakpastian keuangan, persediaan makanan yang tidak memadai, tidak adanya latihan fisik dan aktivitas rekreasi yang terbatas (tidak memiliki rekreasi) memiliki hubungan yang signifikan dengan stres, kecemasan, depresi, dan gejala pasca-trauma.

\section{SIMPULAN}

Kajian literatur menunjukkan bahwa faktor-faktor seperti: durasi waktu karantina yang lama, kekhawatiran akan terinfeksi, status pelajar (terutamanya pada tingkat pascasarjana), jenis kelamin perempuan, riwayat kesehatan yang buruk sebelum pandemi, lokasi tinggal dekat dengan episentrum COVID19 , kemampuan manajemen emosional yang rendah, serta ketidakpastian akan keadaan finansial dan makanan yang cukup. Selanjutnya, faktor seperti informasi medis yang akurat, perilaku pencegahan, aktivitas olahraga yang cukup, pola makan yang teratur, serta adanya aktivitas rekreasi menjadi faktor yang mampu melindungi kalangan dewasa muda dari gejala depresi dan ansietas.

\section{SARAN}

Penelitian lebih lanjut dengan lokasi yang berbeda dan metode

pengambilan sampel yang lebih acak diharapkan dapat dilakukan sehingga bukti hasil studi menjadi semakin kuat. Selain itu, hasil penelitian ini sejatinya dapat dijadikan sebagai acuan untuk pemerintah maupun badan negara lain dalam menetapkan kebijakan intervensi dalam situasi pandemi untuk meminimalisir dampak negatif terhadap kesehatan mental pelajar dan juga masyarakat (khususnya dewasa muda). Sebagai contohnya, apabila ditinjau dari kelima literatur tersebut, tidak ada literatur yang menyebutkan bahwa pembatasan sosial merupakan salah satu indikator penyebab peningkatan prevalensi gangguan mental pada pelajar saat ini. Oleh sebab itu, Pembatasan Sosial Berskala Besar (PSBB) ataupun peraturan pembatasan lainnya merupakan penyelesaian yang dapat dikonsiderasikan dalam menghentikan peningkatan penyebaran 
COVID-19 dan juga menjaga kesehatan mental pelajar dengan baik.

Selain itu, karena influx berita mengenai COVID-19 merupakan salah satu indikator utama, maka sebagai bentuk intervensi, pemerintah dapat lebih baik dalam mengemas informasi publik mengenai COVID-19. Dibalik itu, pemerintah juga mepunyai opsi alternatif untuk mengideasi program-program interaktif yang dapat diikuti oleh pelajar di Indonesia. Hal ini didasarkan hasil tinjauan literartur yang menunjukkan bahwa pelajar yang beraktivitas selama pandemi mempunyai indikasi gejala depresi dan ansietas yang lebih rendah. Alhasil, alterasi-alterasi ini dapat mencegah adanya potensi peningkatan gangguan mental selama wabah COVID19 maupun pandemi-pandemi yang mungkin timbul di masa depan.

\section{UCAPAN TERIMA KASIH}

Tim penulis mengucapkan terima kasih atas bantuan dan dukungan dari dosen sekalian termasuk kepada Joshua Moses atas bimbingan dan arahannya selama ini.

\section{DAFTAR PUSTAKA}

1. Djalante R, Lassa J, Setiamarga D, Sidjatma A, Indrawan M, Haryanto $B$, et al. Review and analysis of current responses to COVID-19 in Indonesia: Period of January to March 2020. Progress in Disaster Medicine [internet]. 2020 Apr 6 [cited 2020 Sep 3]; 6: 100091. Available from: https://www.ncbi.nlm.nih.gov/pmc/a rticles/PMC7149002/

2. Vindegaard N, Benros ME. COVID19 pandemic and mental health consequences: Systematic review of the current evidence. Brain Behav immune [internet]. 2020 May 30 [cited 2020 Sep 7]. Available from:

https://www.ncbi.nlm.nih.gov/pmc/a rticles/PMC7260522/

3. Lotfi M, Hamblin MR, Rezaei N. COVID-19: Transmission, prevention, and potential therapeutic opportunities. Clin Chim
Acta [internet]. 2020 Sep [cited 2020 Sep 5]; 508: 254-66. Available from: https://www.ncbi.nlm.nih.gov/pmc/a rticles/PMC7256510/

4. Huang Y, Zhao N. Generalized anxiety disorder, depressive symptoms and sleep quality during COVID-19 outbreak in China: a web-based cross-sectional survey. Psychiatry Res [internet]. 2020 Jun [cited 2020 Sep 4]; 288: 112954. Available from: https://pubmed.ncbi.nlm.nih.gov/32 325383/

5. Malhi GS, Mann JJ. Depression. Lancet [internet]. 2018 Nov 21 [cited 2020 Sep 5]; 2299-312. Available from:

https://pubmed.ncbi.nlm.nih.gov/30 396512/

6. Cui R. EDITORIAL A Systematic Review of Depression. Curr Neuropharmacol [internet]. $2015 \mathrm{Jul}$ [cited 2020 Sep 9]; 13(4) 480. Available from: https://www.ncbi.nlm.nih.gov/pmc/a rticles/PMC4790400/

7. Kementerian Kesehatan Republik Indonesia. Hasil Utama Riskesdas 2018 [internet]. Indonesia: Badan Peneltian dan Pengembangan Kesehatan; 2018 [cited 2020 sep 4]. Avaiable from: https://kesmas.kemkes.go.id/assets /upload/dir_519d41d8cd98f00/files/ Hasil-riskesdas-2018_1274.pdf

8. Munir S, Takov V. Generalized anxiety disorder (GAD), Treasure Island: StatPearls Publishing; 2020 Jan [cited 2020 Sep 6]. Avaible from:

https://www.ncbi.nlm.nih.gov/books/ NBK441870/

9. Bandelow B, Boerner RJ, Kesper S, Linden $\mathrm{M}$, Wittchen $\mathrm{H}$, Moller $\mathrm{H}$. The Diagnosis and Treatment of Generalized Anxiety Disorder. Dtsch Arztebl Int [internet]. 2013 [cited 2020 Sep 3]; 110(17): 300-10. Available from: https://pubmed.ncbi.nlm.nih.gov/23 671484/

10. Parekh R. What is mental illness? [internet]. Washington: American Psychiatric Association; 2018 Aug [cited 2020 Sep 7]. Available from: https://www.psychiatry.org/patientsfamilies/what-is-mental-illness 
11. Ritchie H, Roser M. Mental health [internet]. United Kingdom: Our World in Data; 2018 April [cited 2020 Sep 9]. Available from: https://ourworldindata.org/mentalhealth

12. Menard C, Hodes GE, Russo SJ. Pathogenesis of depression: insights from human and rodent studies. Neuroscience [internet]. 2016 May [cited 2020 Sep 6]; 321: 138-62. Available from: https://www.ncbi.nlm.nih.gov/pmc/a rticles/PMC4664582/

13. Patriquin MA, Mathew SJ. The Neurobiological Mechanisms of Generalized Anxiety Disorder and Chronic Stress. Chronic Stress [internet]. 2017 Jan [cited 2020 Sep 7]; 1: 2470547017703993 . Available from:

https://www.ncbi.nlm.nih.gov/pmc/a rticles/PMC5832062/

14. Wang $\mathrm{C}$, Pan R, Wan $\mathrm{X}$, Tan $\mathrm{Y}, \mathrm{Xu}$ $\mathrm{L}$, Ho CS, et al. Immediate Psychological Responses and Associated Factors during the Initial Stage of the 2019 Coronavirus Disease (COVID-19) Epidemic among the General Population in China. Int J Environ Res Public Health [internet]. 2020 Mar [cited 2020 Sep 9]; 17(5): 1729. Available from:

https://www.ncbi.nlm.nih.gov/pmc/a rticles/PMC7084952/

15. Feng $\mathrm{Y}$, Zong $\mathrm{M}$, Yang Z, Gu W, Dong D, Qiao Z. When altruists cannot help: the influence of altruism on the mental health of university students during the COVID-19 pandemic. Global Health [internet]. 2020 [cited 2020 Sep 4]; 16: $61 . \quad$ Available from: https://www.ncbi.nlm.nih.gov/pmc/a rticles/PMC7348110/

16. Xiao H, Su W, Li M, Tao F, Wu X, $\mathrm{Yu} Y$, et al. Social Distancing among Medical Students during the 2019 Coronavirus Disease Pandemic in China: Disease Awareness, Anxiety Disorder, Depression, and Behavioral Activities. Int J Environ Res Public Health [internet]. 2020 Jul; 17(14): 5047. Available from: https://www.ncbi.nlm.nih.gov/pmc/a rticles/PMC7399842/

17. Chen R, Liang S, Peng Y, Li X, Chen $J$, Yang $S$, et al. Mental health status and change in living rhythms among college students in China during the COVID-19 pandemic: A large-scale survey. J Psychosom Res [internet]. 2020 Aug 15 [cited 2020 Sep 3]; 137: 110219. Available from: https://www.ncbi.nlm.nih.gov/pmc/a rticles/PMC7428432/

18. Khan $A H$, Sultana $S$, Hossain $S$, Hasan MT, Ahmed HU, Sikder T. The impact of COVID-19 pandemic on mental health \& wellbeing among home-quarantined Bangladeshi students: A cross-sectional pilot study. J Affect Disord [internet]. 2020 Aug 7 [cited 2020 Sep 4]. Available from: https://www.ncbi.nlm.nih.gov/pmc/a rticles/PMC7410816/ 
MPIRAN 1. RINGKASAN HASIL STUDI

\begin{tabular}{|c|c|c|c|c|c|c|c|c|}
\hline $\begin{array}{l}\text { Penuli } \\
\text { s dan } \\
\text { Tahun }\end{array}$ & Lokasi & $\begin{array}{c}\text { Desai } \\
\text { n } \\
\text { Studi }\end{array}$ & $\begin{array}{l}\text { Waktu } \\
\text { Studi }\end{array}$ & $\begin{array}{l}\text { Ukuran } \\
\text { Sampel }\end{array}$ & $\begin{array}{c}\text { Rata- } \\
\text { Rata/Mayo } \\
\text {-ritas Usia } \\
\text { Sampel } \\
\text { (tahun) }\end{array}$ & $\begin{array}{c}\text { Metode } \\
\text { Identifikasi }\end{array}$ & $\begin{array}{c}\text { Metode } \\
\text { Pengukuran dan } \\
\text { Klasifikasi }\end{array}$ & Hasil \\
\hline $\begin{array}{l}\text { Wang } \\
\text { C, } \\
2020\end{array}$ & China & $\begin{array}{l}\text { Cross- } \\
\text { section } \\
\text { al }\end{array}$ & $\begin{array}{l}\text { Januari- } \\
2 \\
\text { Februari } \\
2020\end{array}$ & $\begin{array}{l}1210 \\
\text { respond } \\
\text { en dari } \\
194 \text { kota }\end{array}$ & $\begin{array}{l}21,4-30,8 \\
(53,1 \%)\end{array}$ & $\begin{array}{l}\text { Survei daring } \\
\text { dengan } \\
\text { strategi } \\
\text { sampling } \\
\text { snow ball }\end{array}$ & 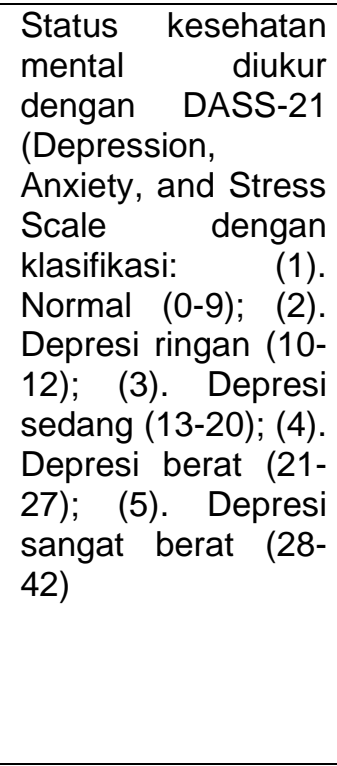 & $\begin{array}{l}\text { Sejumlah } 53,8 \% \text { responden menilai dampak psikologis dari } \\
\text { wabah tergolong sedang atau parah; } 16,5 \% \text { melaporkan } \\
\text { gejala depresi sedang hingga berat; } 28,8 \% \text { melaporkan } \\
\text { gejala kecemasan sedang hingga berat; dan } 8,1 \% \\
\text { melaporkan tingkat stres sedang hingga berat. Sebagian } \\
\text { besar responden menghabiskan } 20-24 \text { jam per hari di rumah } \\
(84,7 \%) \text {; khawatir anggota keluarga mereka tertular COVID- } \\
19(75,2 \%) \text {; dan merasa puas dengan jumlah informasi } \\
\text { kesehatan yang tersedia (75,1\%). Jenis kelamin perempuan, } \\
\text { status pelajar, gejala fisik tertentu (misalnya, mialgia, pusing, } \\
\text { coryza), dan status kesehatan yang dinilai buruk secara } \\
\text { signifikan terkait dengan dampak psikologis yang lebih besar } \\
\text { dari wabah dan tingkat stres, kecemasan, dan depresi yang } \\
\text { lebih tinggi ( } \mathrm{p} \text {, 0,05). Adaya informasi kesehatan yang } \\
\text { terkini dan akurat (misalnya, pengobatan, situasi wabah } \\
\text { lokal) dan tindakan pencegahan tertentu (misalnya, } \\
\text { kebersihan tangan dan memakai masker) menunjukkan } \\
\text { dampak psikologis yang lebih rendah dari wabah dan tingkat } \\
\text { stres yang lebih rendah, kecemasan, dan depresi (p <0,05). }\end{array}$ \\
\hline $\begin{array}{l}\text { Feng } \\
Y, \\
2020\end{array}$ & China & $\begin{array}{l}\text { Cross- } \\
\text { section } \\
\text { al }\end{array}$ & $\begin{array}{l}8-28 \\
\text { Februari } \\
2020\end{array}$ & $\begin{array}{l}1346 \\
\text { mahasis } \\
\text { wa }\end{array}$ & $\begin{array}{l}19.76 \pm \\
2.23 \text { tahun }\end{array}$ & $\begin{array}{l}\text { survei daring } \\
\text { dengan } \\
\text { strategi } \\
\text { simpe cluster } \\
\text { sampling }\end{array}$ & $\begin{array}{lr}\text { Ansietas } & \text { diukur } \\
\text { dengan } & \text { 7-item } \\
\text { Generalized } & \\
\text { Anxiety } & \text { Disorder } \\
\text { Scale } & \text { (GAD-7). } \\
\text { Depresi } & \text { ditentukan } \\
\text { melalui } & \text { self-report } \\
\text { 9-item } & \text { Patient }\end{array}$ & $\begin{array}{l}\text { Semakin tinggi risiko yang dirasakan responden, semakin } \\
\text { banyak pengaruh negatif yang mereka tunjukkan }(\beta=0,16 \text {, } \\
p<0,001) \text {, dan dengan demikian, responden merasa lebih } \\
\text { cemas dan tertekan }(\beta=0,134, p<0,001) \text {; Namun, } \\
\text { hubungan antara persepsi risiko dan pengaruh negatif ini } \\
\text { dimoderasi oleh altruisme. }\end{array}$ \\
\hline
\end{tabular}




\begin{tabular}{|c|c|c|c|c|c|c|c|c|}
\hline & & & & & & & 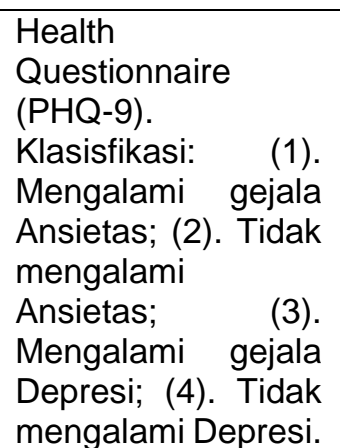 & \\
\hline $\begin{array}{l}\text { Xiao } \\
\mathrm{H}, \\
2020\end{array}$ & $\begin{array}{l}\text { Beijing } \\
\text { dan } \\
\text { Wuhan } \\
\text {, China }\end{array}$ & $\begin{array}{l}\text { Cross- } \\
\text { section } \\
\text { al }\end{array}$ & $\begin{array}{l}4-12 \\
\text { Februari } \\
2020\end{array}$ & $\begin{array}{l}933 \\
\text { mahasis } \\
\text { wa } \\
\text { kedokter } \\
\text { an }\end{array}$ & $\begin{array}{l}17-24 \\
(80,9)\end{array}$ & $\begin{array}{l}\text { Survei daring } \\
\text { dengan } \\
\text { strategi } \\
\text { simple } \\
\text { cluster } \\
\text { sampling }\end{array}$ & $\begin{array}{lr}\text { Ansietas } & \text { diukur } \\
\text { dengan } & \text { 7-item } \\
\text { Generalized } & \\
\text { Anxiety } & \text { Disorder } \\
\text { Scale } & \text { (GAD-7). } \\
\text { Depresi } & \text { ditentukan } \\
\text { melalui } & \text { self-report } \\
\text { 9-item } & \text { Patient } \\
\text { Health } & \\
\text { Questionnaire } & \\
\text { (PHQ-9). } & \\
\text { Klasifikasi: } & (1) . \\
\text { Normal; } & (2) . \\
\text { Ringan; } & (3) . \\
\text { Sedang; (4). } & \text { Berat }\end{array}$ & $\begin{array}{l}\text { Dari sejumlah } 933 \text { siswa, } 898(96,2 \%) \text { melaporkan sering } \\
\text { memakai masker saat keluar, } 723(77,5 \%) \text { melaporkan } \\
\text { mencuci tangan setiap hari dengan sabun, } 676(72,5 \%) \\
\text { mencuci tangan segera setelah tiba di rumah, dan } 914 \\
(98,0 \%) \text { melaporkan tinggal di rumah sebanyak mungkin. } \\
\text { Prevalensi gangguan kecemasan } 17,1 \% \text { dan depresi } 25,3 \% \text {. } \\
\text { Regresi logistik multivariabel menunjukkan kecemasan } \\
\text { dikaitkan dengan status mahasiswa pascasarjana (rasio } \\
\text { odds (aOR) }=2.0 \text {; interval kepercayaan } 95 \%(\mathrm{Cl}): 1.2-3.5) \text {, } \\
\text { pikiran atau tindakan negatif (aOR }=1.6 ; 95 \% \mathrm{Cl}: 1.4-1.7) \text {, } \\
\text { dan merasa tertekan (aOR }=6.8 ; 95 \% \mathrm{Cl}: 4.0-11.7) \text {. } \\
\text { Mahasiswa Beijing secara signifikan lebih kecil } \\
\text { kemungkinannya untuk mengalami kecemasan } \\
\text { dibandingkan dengan mereka yang berada di episentrum } \\
\text { pandemic, Wuhan (aOR = 0,9; 95\% Cl: 0,8-1,0), tetapi } \\
\text { depresi tidak berbeda. Depresi dikaitkan dengan mahasiswi } \\
\text { (aOR }=2.0 ; 95 \% \mathrm{Cl}: 1.2-3.3) \text {, pikiran atau tindakan negatif } \\
\text { (aOR }=1.7 ; 95 \% \mathrm{Cl}: 1.5-1.9) \text {, dan gangguan kecemasan } \\
\text { (aOR }=5.8 ; 95 \% \mathrm{Cl}: 3.4-9.9) \text {. }\end{array}$ \\
\hline $\begin{array}{l}\text { Chen } \\
\text { R, } \\
2020\end{array}$ & China & $\begin{array}{l}\text { Cross- } \\
\text { section } \\
\text { al }\end{array}$ & $\begin{array}{l}13-22 \\
\text { Februari } \\
2020\end{array}$ & $\begin{array}{l}361.969 \\
\text { mahasis } \\
\text { wa }\end{array}$ & $\begin{array}{l}19-22 \\
(84.3 \%)\end{array}$ & $\begin{array}{l}\text { Survei daring } \\
\text { dengan } \\
\text { metode }\end{array}$ & $\begin{array}{lr}\text { Depresi } & \text { ditentukan } \\
\text { melalui } & \text { self-report } \\
\text { 9-item } & \text { Patient } \\
\text { Health } & \end{array}$ & $\begin{array}{l}\text { Sejumlah } 7,7 \% \text { mahasiswa menunjukkan gejala depresi } \\
\text { selama pandemi COVID-19. Mahasiswa dengan gejala } \\
\text { depresi berkaitan dengan kemampuan manajemen } \\
\text { emosinya yang rendah. Kegiatan menjelajahi informasi }\end{array}$ \\
\hline
\end{tabular}


cluster

sampling

Questionnaire

(PHQ-9).

Klasifikasi:

Mengalami

Depresi; (2). Tidak

mengalami Depresi.

$\begin{array}{lllllll}\text { Khan } & \text { Bangla } & \text { Cross- } & 9-23 & 505 & 20-24 & \text { Survei daring } \\ \text { AH, } & \text { desh } & \text { section } & \text { April } & \text { mahasis } & (78,42 \%) & \text { dengan } \\ \mathbf{2 0 2 0} & & \text { al } & 2020 & \text { wa } & & \text { metode } \\ & & & & & & \text { sampling }\end{array}$

convenience

(Depression,

mental diukur

dengan DASS-21

Anxiety, and Stress

Scale)

dengan

klasifikasi:

(1).

列

1,01 hingga 6,40), subskala kecemasan DASS (B = 3,95, Cl

Depresi ringan (10- 95\%: 1,95 hingga 5,96), subskala depresi DASS (B = 3,82,

12); (3). Depresi CI 95\%: 0,97 hingga 6,67) dan skala IES (B =7,52, CI 95\%:

sedang (13-20); (4). 3,58 hingga 11,45). Selain itu, ketakutan akan infeksi,

Depresi berat (21- ketidakpastian keuangan, persediaan makanan yang tidak

27); (5). Depresi memadai, tidak adanya latihan fisik dan aktivitas rekreasi sangat berat (28- yang terbatas (tidak memiliki rekreasi) memiliki hubungan

42). Kondisi distres yang signifikan dengan stres, kecemasan, depresi, dan diukur dengan gejala pasca-trauma. Sejumlah 28,5\% dari responden mengalami stres, 33,3\% khusus dari tahap ringan hingga berat dalam hal tingkat keparahan melalui survei IES. Responden yang menyadari

Scale (IES)

COVID-19 selama 3 jam per hari terbukti berhubungan menyenangkan ditemukan berpengaruh dengan munculnya 
LAMPIRAN 2. PENILAIAN KUALITAS LITERATUR

The National Institutes of Health $(\mathrm{NIH})$ quality assessment tool for observational cohort and cross-sectional studies

\begin{tabular}{|c|c|c|c|c|c|c|}
\hline \multirow[b]{2}{*}{ No. } & \multirow[t]{2}{*}{ Website: https://www.nhlbi.nih.gov/health-topics/study-quality-assessment-tools } & \multicolumn{5}{|c|}{ Penulis, Tahun } \\
\hline & & Wang C, 2020 & $\begin{array}{l}\text { Feng Y, } \\
2020\end{array}$ & $\begin{array}{c}\text { Xiao H, } \\
2020\end{array}$ & $\begin{array}{c}\text { Chen R, } \\
2020\end{array}$ & Mst AHK, 2020 \\
\hline 1 & Apakah pertanyaan atau tujuan penelitian dalam makalah ini dinyatakan dengan jelas? & Ya & Ya & Ya & Ya & Ya \\
\hline 2 & Apakah populasi penelitian ditentukan dan ditentukan dengan jelas? & Ya & Ya & Ya & Ya & Ya \\
\hline 3 & Apakah tingkat partisipasi orang yang memenuhi syarat minimal $50 \% ?$ & Ya & Ya & Ya & Ya & Ya \\
\hline 4 & $\begin{array}{l}\text { Apakah semua subjek dipilih atau direkrut dari populasi yang sama atau serupa (termasuk periode waktu yang sama)? } \\
\text { Apakah kriteria inklusi dan eksklusi untuk berada dalam penelitian ditentukan sebelumnya dan diterapkan secara } \\
\text { seragam untuk semua peserta? }\end{array}$ & Ya & Ya & Ya & Ya & Ya \\
\hline 5 & Apakah justifikasi ukuran sampel, deskripsi kekuatan, atau perkiraan varians dan efek disediakan? & $\mathrm{Ya}$ & $\mathrm{Ya}$ & Ya & Ya & Ya \\
\hline 6 & Untuk analisis dalam studi, apakah eksposur yang diminati diukur sebelum hasil diukur? & $\mathrm{Ya}$ & Ya & Ya & Ya & Ya \\
\hline 7 & $\begin{array}{l}\text { Apakah jangka waktunya cukup sehingga orang bisa berharap untuk melihat hubungan antara eksposur dan hasil jika } \\
\text { ada? }\end{array}$ & $\mathrm{Ya}$ & Ya & Ya & Ya & $\mathrm{Ya}$ \\
\hline 8 & $\begin{array}{l}\text { Untuk eksposur yang dapat bervariasi dalam jumlah atau level, apakah penelitian memeriksa berbagai level eksposur } \\
\text { yang terkait dengan hasil (misalnya, kategori eksposur, atau eksposur diukur sebagai variabel kontinu)? }\end{array}$ & $\mathrm{Ya}$ & Tidak & Ya & Tidak & Ya \\
\hline 9 & $\begin{array}{l}\text { Apakah ukuran keterpaparan (variabel independen) didefinisikan dengan jelas, valid, dapat diandalkan, dan diterapkan } \\
\text { secara konsisten di semua peserta studi? }\end{array}$ & $\mathrm{Ya}$ & $\mathrm{Ya}$ & Ya & $\mathrm{Ya}$ & $\mathrm{Ya}$ \\
\hline 10 & Apakah keterpaparan dinilai lebih dari sekali sepanjang waktu? & Tidak & Tidak & Tidak & Tidak & Tidak \\
\hline 11 & $\begin{array}{l}\text { Apakah ukuran hasil (variabel dependen) didefinisikan dengan jelas, valid, dapat diandalkan, dan diterapkan secara } \\
\text { konsisten di semua peserta studi? }\end{array}$ & $\mathrm{Ya}$ & Ya & Ya & Ya & Ya \\
\hline 12 & Apakah penilai hasil tidak mengetahui status keterpaparan peserta? & Tidak & Tidak & Tidak & Tidak & Tidak \\
\hline 13 & Apakah mangkir setelah baseline $20 \%$ atau kurang? & Tldak & Tidak & Tidak & Tidak & Tidak \\
\hline 14 & $\begin{array}{l}\text { Apakah variabel perancu potensial utama diukur dan disesuaikan secara statistik untuk dampaknya terhadap hubungan } \\
\text { antara keterpaparan dan hasil? }\end{array}$ & $\mathrm{Ya}$ & $\mathrm{Ya}$ & $\mathrm{Ya}$ & $\mathrm{Ya}$ & $\mathrm{Ya}$ \\
\hline & Penilaian Kualitas & Baik & Cukup & Baik & Cukup & Baik \\
\hline
\end{tabular}

